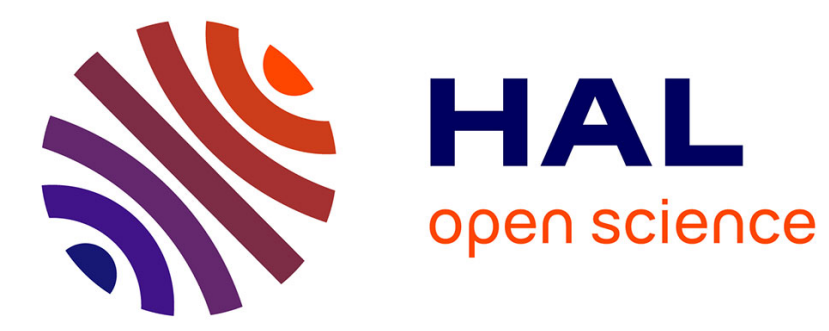

\title{
Development of the Auto Parts Industry in Brazil
}

Nivaldo Luiz Palmeri, Oduvaldo Vendrametto, João Gilberto Mendes dos Reis

\section{To cite this version:}

Nivaldo Luiz Palmeri, Oduvaldo Vendrametto, João Gilberto Mendes dos Reis. Development of the Auto Parts Industry in Brazil. IFIP International Conference on Advances in Production Management Systems (APMS), Sep 2014, Ajaccio, France. pp.505-512, 10.1007/978-3-662-44733-8_63 . hal01387313

\section{HAL Id: hal-01387313 \\ https://hal.inria.fr/hal-01387313}

Submitted on 25 Oct 2016

HAL is a multi-disciplinary open access archive for the deposit and dissemination of scientific research documents, whether they are published or not. The documents may come from teaching and research institutions in France or abroad, or from public or private research centers.
L'archive ouverte pluridisciplinaire $\mathbf{H A L}$, est destinée au dépôt et à la diffusion de documents scientifiques de niveau recherche, publiés ou non, émanant des établissements d'enseignement et de recherche français ou étrangers, des laboratoires publics ou privés. 


\title{
Development of the Auto Parts Industry in Brazil
}

\author{
Nivaldo Luiz Palmeri, Oduvaldo Vendrametto, and João Gilberto Mendes dos \\ Reis \\ Paulista University, Postgraduate Studies Program in Production Engineering \\ Dr. Bacelar 1212, 04026-002 São Paulo, Brazil

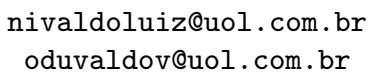

\begin{abstract}
The purpose of this article is to demonstrate the evolution of the auto part industry regarding the Brazilian Automobile Industry. In 2013, even as Brazil ranked as the fifth largest producer of vehicles in the world, the commercial balance reached a new level of deficit. The studied hypothesis is that the national auto part industry is producing items of lesser technological value and importing items of greater value. This research highlights the importance of the technological development and the strengthening of competitiveness in the autopart industry for the success of the Inovar-Auto program.
\end{abstract}

Keywords. Auto part, Automobile industry, Inovar-Auto program.

\section{Introduction}

The Inovar-Auto program, developed by the Brazilian government [1] aims to reduce the number of imported auto parts in a growing domestic vehicle production. For that, the law offers tax incentives for companies that replace imported for auto parts produced in Brazil. The goal is to launch technology development in the country.

However, it can be noted in recent years that the complex auto parts tend to be imported from developed markets such as Europe, USA and Japan, while the domestic industry is responsible for complementary parts, such as the peripheral supplier. The Inovar-Auto program, implemented in 2012, still does not allow its effects to be fully observed.

Throughout its history, Brazil has been a country that tends to buy technology and not develop them; the automobile industry is an example of this behavior. Corporations throughout the whole country are all transnational. All the developed technology, even by Brazilian engineers, are linked to and patented abroad. The lack of long-term well-defined policies, development, and control stimulates import. In addition, there are difficulties in the development of technology, poor qualification of the workforce and low level of education in the 
country. Of the 100 largest Brazilian companies of this sector, only five develop technology and one is of national origin [2].

This research studies the automobile and auto parts industry in Brazil from 2001 to 2012, featuring a pre-Inovar-Auto panorama. For this, the billing of the automotive and auto parts industry located in the country are evaluate, along with the volume of the import of parts.

\section{Methodology}

For this study, data was collected from the directories of ANFAVEA (National Association of Automobile Manufacturers) [3], DIEESE (Department of Statistics and Socioeconomic Studies) [4], and SINDIPEÇAS / ABIPEÇAS (National Association of Automotive Components Industry / Brazilian Association of Automotive Parts Industry) [5].

Once the data was identified, the next stages of the research were as following: (1) evaluation of the progress of vehicles manufacturers net sales in Brazil, including cars, light commercial vehicles, trucks and buses; (2) evaluation of the income and import of auto parts evolution, including the automobile industry, the aftermarket, exports, and intersectorial (other manufacturers) to determine the behavior of the Brazilian auto parts industry.

Objective evaluation findings have led to the billing growth of automobiles in the reference period, 2001/12 (Eq.1)

$$
P=\frac{v a}{v b} * 100
$$

Where, $v b$ corresponds to the billing in 2001 and $v a$ in 2012.

Thus the development of the billing of vehicles in 2012 was given by:

$$
P=\frac{83.676}{45.818} * 100=182.6
$$

The choice of the period between 2001 and 2012 for conducting the research is justified due to the global emphasis Brazil has been receiving, becoming the fifth largest producer of vehicles in the world. Furthermore, the crescent income of the Brazilian population favored the sales of vehicles, growing year by year, while the other sale areas find themselves stagnated. Finally, in 2012, the InovarAuto program was announced by the Brazilian government as a way to boost the domestic industry and stimulate the thickening of the Brazilian automotive chain. 
It is important to emphasize that in the period between 2002 and 2012, the total production of automobiles (excluding CKD - Complete Knock Down) went from 1.63 million to 3.41 million units, a growth of $108.5 \%$; with highlight to the light commercial vehicles segment that grew $251.4 \%$ during the cited period, followed by the truck sector, that presented a $216.4 \%$ growth during the same period [4].

Based on the data obtained from survey and the comparative calculations performed with the indicators of the automobile and auto parts industry, an analysis will be made of the Brazilian auto parts industry technological development.

\section{Inovar-Auto}

The Brazilian government's attempt to create the Inovar-Auto program is to promote technological research and enable the country's production to make more modern parts and components for the automobile industry, reducing the dependence on exportations and its consequences.

The automotive sector, due to its high competitiveness, continually invests in research and innovation. It is the third among the sectors that most invests; from $3 \%$ to $5 \%$. Modestly, in 2013, the Inovar-Auto program proposed an initial investment of only $0.15 \%$ over the gross profit, reaching $0.5 \%$ in 2017 and furthered the application in engineering and basic technology to $0.5 \%$, also in 2013, with a limit of $1 \%$ in 2017. Unlike to this logic, system suppliers, who are responsible globally for $60 \%$ of innovations in the segment, do not participate in the incentive to boost technological research. Therefore, the expectation of effective technological evolution is reduced [6].

The collected data leads to the hypothesis that the Brazilian industry (automakers and auto parts) are directing their production to items of smaller technological value, while they search for item of greater value available in centers such as Japan, European Union and the United States.

The main targets of the Inovar-Auto program are: (1) create favorable conditions of competitiveness for companies that produce cleaner and safer vehicles; (2) invest in the local supply chain and industrial engineering; (3) increase actions of the local R\&D [3] and [4].

The consolidation of the country's competence is a necessary to maintain and improve their competitiveness. To follow this evolution, the existence of qualified suppliers in great quantities and development of global technologies is necessary, without, which the system would become fragile and dependent. Therefore, the national auto parts industry should be a priority in a proposition such as the Inovar-Auto [7].

\section{Automobile and Auto Parts Industry in Brazil}

The Brazilian automobile industry represents, in 2014, almost $25 \%$ of the industrial GDP and 5\% of the total GDP, with billings above 100 billion dollars. 
Brazil has 61 industrial units among 46 cities in 10 states; with these numbers tending to increase [3].

The industry moves a chain that includes manufacturers, suppliers of raw materials, auto parts distributors, gas stations, insurance companies, repair shops, tire repair shops, media companies, and advertising agencies, among others, all interconnected and employing millions of workers [3].

The auto parts industry is directly related to the automobile industry. Their activities were initiated in the 1930s, and vigorously expanded in the 1950s. It was driven by the pioneer plan established by President Juscelino Kubitschek, who sought the introduction of a national automotive industry [8].

In 1990, the Brazilian auto parts industry began to face the scenario called globalization. The release of imported goods and economic stability encouraged the entrance of foreign products of better quality [8].

In the beginning of the XXI century, the process of global automobile industry restructuring repositioned brands and manufactures, expanding its global characteristics and enabling businesses to compete profitably in different regional markets. Taking the automakers as an example, the auto parts, machinery and equipment industry intensified its strategy of global competition, aiming to take the place of local suppliers [4].

In 2011, the trade balance of the Brazilian automobile industry has reached new level of trade deficit, reaching the 5.88 billion dollars mark: exports totaled 12.78 billion dollars, while imports totaled 18.66 billion [4].

In 2013, Brazil appeared as the fourth largest market in sales of light vehicles in the world, behind China, USA and Japan. The country has been consolidating its importance in the global market, with forecasts to double the sales by 2025 ; significantly increasing its share of the major brands in its market, especially Korean, Japanese and Chinese [4].

Among the foreign auto parts companies installed in Brazil, many plan to increase their investments in the country, such as the Continental company, which intends to double its production by 2015, and Magna and Dana who bought companies to strengthen their capacity. New companies are also planning to enter the country, such as the Korean companies DYMOS, Mobis, THN, and several Chinese suppliers [9].

The new industrial policy of the automotive sector (Inovar-Auto) is part of a long-term plan (2013-2017) with three main goals: (1) to stimulate investment and innovation; (2) to protect the domestic industry and (3) to growth Brazilian market against imports. Over the past five years, a sharp increase in the trade deficit and in the automotive and auto parts industry put in doubt the future of the national supply chain. This is not a small problem and it interferes in the local capacity to design parts, systems, and products. The analysis shows that Brazil's chances of becoming a center for the production and marketing of vehicle lacks technological expertise, as well as local projects with lower prices due to increased competition [10]. 


\section{Results and Discussion}

\subsection{Brazilian Production and Sales of Vehicles}

The growth in production of vehicles in Brazil grew alongside with the billing, from 2001 to 2012 . While the production increased $188.8 \%$, going from 1.8 million units built in 2001 to 3.4 million in 2012, the income increased from 45,818 million dollars to 83,676 million dollars during the same period of time, maintaining the balance shown in Table 1 . Likewise, the profits per automobile remained stable, with a minimum cost of 22,184.77 million dollars in 2005, a maximum of 25,214.68 million dollars in 2001, and an average of 23,732.90 million dollars.

Table 1. Comparison between production and sales of vehicles.

\begin{tabular}{|c|c|c|c|c|c|c|}
\hline \multirow[t]{2}{*}{ Year } & \multicolumn{2}{|c|}{ Production } & \multicolumn{2}{|c|}{ Billing } & \multicolumn{2}{|c|}{ Billing/Production } \\
\hline & Units & Growth(\%) & US\$ $(*)$ & Growth(\%) & $\mathbf{U S} \$(*)$ & Growth(\%) \\
\hline 2001 & $1,817,116$ & 100.0 & 45,818 & 100.0 & 25,214 & 100.0 \\
\hline 2002 & $1,791,530$ & 98.6 & 43,402 & 94.7 & 24,226 & 96.1 \\
\hline 2003 & $1,827,791$ & 100.6 & 42,039 & 91.8 & 22,999 & 91.2 \\
\hline 2004 & $2,317,227$ & 127.5 & 52,009 & 113.5 & 22,444 & 89.0 \\
\hline 2005 & $2,530,249$ & 139.2 & 56,133 & 122.5 & 22,184 & 88.0 \\
\hline 2006 & $2,612,329$ & 143.8 & 60,110 & 131.2 & 23,010 & 91.3 \\
\hline 2007 & $2,980,163$ & 164.0 & 71,715 & 156.5 & 24,064 & 95.4 \\
\hline 2008 & $3,216,381$ & 177.0 & 76,245 & 166.4 & 23,705 & 94.0 \\
\hline 2009 & $3,183,482$ & 175.2 & 77,259 & 168.6 & 24,268 & 96.2 \\
\hline 2010 & $3,646,548$ & 200.7 & 86,066 & 187.8 & 23,602 & 93.6 \\
\hline 2011 & $3,442,787$ & 189.5 & 84,980 & 185.5 & 24,683 & 97.9 \\
\hline 2012 & $3,430,604$ & 188.8 & 83,676 & 182.6 & 24,391 & 96.7 \\
\hline
\end{tabular}

* Million dollars

Source: Adapted [3]

\subsection{Revenues of the Automobile Industry versus Auto Parts versus the Import of Auto Parts}

When comparing the evolution of the automotive and auto parts industry's income between 2001 and 2012, the motor vehicles obtained a growth of $182.6 \%$, while the auto parts grew $351.3 \%$; sales of auto parts was 1.9 times greater than that of vehicles. During the same period, the imported auto parts presented a growth rate of $410.5 \%$, an increase of $16.9 \%$ compared to auto parts and 2.2 times greater than that of the motor vehicles (Table 2)

The main variables used to explain the growth in auto parts import are related to the acknowledgement of the national currency towards the major currencies; increased costs of labor; elevated Brazilian tax revenue, and the relocation of new projects to more competitive countries. The combination of these 
Table 2. Billing and imports in US dollar millions

\begin{tabular}{lccrrrr}
\hline Year & \multicolumn{2}{c}{ Production } & \multicolumn{2}{c}{ Billing } & \multicolumn{2}{c}{ Billing/Production } \\
& Units & Growth(\%) & US\$ $(*)$ & Growth(\%) & US\$ $\left(^{*}\right)$ & Growth(\%) \\
\hline 2001 & 45,818 & 100.0 & 11,903 & 100.0 & 4,416 & 100.0 \\
2002 & 43,402 & 94.7 & 11,309 & 95.0 & 4,147 & 93.9 \\
2003 & 42,039 & 91.8 & 13,330 & 112.0 & 4,504 & 102.0 \\
2004 & 52,009 & 113.5 & 18,548 & 155.8 & 5,825 & 131.9 \\
2005 & 56,133 & 122.5 & 25,263 & 212.2 & 7,070 & 160.1 \\
2006 & 60,110 & 131.2 & 28,548 & 239.8 & 7,237 & 163.9 \\
2007 & 71,715 & 156.5 & 35,064 & 294.6 & 9,772 & 221.3 \\
2008 & 76,245 & 166.4 & 40,992 & 344.4 & 13,558 & 307.0 \\
2009 & 77,259 & 168.6 & 37,895 & 318.4 & 9,508 & 215.3 \\
2010 & 86,066 & 187.8 & 49,767 & 418.1 & 14,855 & 336.4 \\
2011 & 84,980 & 185.5 & 54,512 & 458.0 & 17,999 & 407.5 \\
2012 & 83,676 & 182.6 & 41,818 & 351.3 & 18,129 & 410.5 \\
\hline
\end{tabular}

* Million dollars

Source: Adapted [3]

variables has limited the investments of a large portion of the companies located in Brazil. These persistent factors can lead to de-industrialization of the segment $[3]$.

\subsection{Inovar-Auto Program}

In an attempt to change this scenario, the federal government issued the 7819/12 - October 3, 2012, creating Program to Encourage Technological Innovation and Intensification of the Production Chain of Motor Vehicles or Inovar-Auto, aiming to support the technological development, the innovation, safety, environmental protection, energy efficiency, and quality of vehicles and auto parts [11].

A review of the government's proposition is premature, but is is possible to observe the repercussion of the program in the following recent publications:

Investments in the nationalization of motor production in industries already installed in Brazil: Toyota seeks to nationalize $65 \%$ of Brazilian motor, to be produced in the city of Porto Feliz, with an expectation of attracting 19 new suppliers and producing nationally parts such as block, cylinder head and crankshaft. The new project comes as a direct response to the Brazilian industrial policy, which until the initiation of the new regime, did not demonstrate any interest in fabricating motors in Brazil, even it being the fourth biggest importer of the country, importing 2.5 billion dollars and with a trade deficit of 1.7 billion dollars [12].

Nationalization of engines and components made by independent developers: With the Inovar-Auto program, Cummins rises nationalization. Most of the car motors sold in Brazil are imported from China and receives only minor national contributions. The focal point before the new automotive regime 
was always the lowest cost and, often, the nationalization ceased to be a good option. Now the company seeks to offer products and components (turbochargers and after-treatment systems) with higher domestic content. [13].

Critics on the success of Auto Innovate program: Inovar-Auto protects the profit of inefficient car makers. So far Inovar-Auto program brought no solution to the lack of competitiveness of the domestic automotive industry. After its first year of operation, the Brazilian government's program, which aimed to increase technological inclusion and competitiveness in the domestic automotive industry, did not solve the efficiency problem. Production costs remain as high as ever, above the main competing countries, and the productivity continues to worsen [6].

Research and development projects (R\&D): are blocked by the Ministry of Science, Technology and Innovation (MCTI), due to the lack of definition of what could be considered by the Lei do Bem (Law of Good). The 'Good Law' consolidates tax incentives that corporations can automatically benefit from, as long as they carry out technological research and development of technological innovation. MCTI blocks car makers in the 'Good Law', in the most recent list, 787 companies had their project approved by the 'Good Law' and 218 were cut off for presenting information inaccurate or inconsistent with the law. No vehicle manufacturer installed in Brazil when through the MCTI analysis, due to doubts on the actual application of resources in processes of R\&D. All the initiatives of vehicle manufacturers have been omitted until the release of a better definition of what can be considered research and development for the sector [14].

\section{Conclusion and Outlook}

The practice of the Inovar-Auto program already increased foreign investment. However, as more parts are produced on Brazilian soil, more automakers buy parts and components abroad. Without technological inclusion and with the increase in competitiveness among the automotive parts industry, along with the decrease in other factors that undermine the efficiency of the national automotive industry, the chances of the Inovar-Auto program's success is small.

In this scenario, the ability of the Brazilian government in aligning the technological evolution of the domestic industry with the interests of foreign industries, backed by a consistent long-term policy, is fundamental for the reverse the current situation and the promotion of the long-awaited sustainable development.

\section{References}

1. Brasil: Lei 12.715/2012 (Sep 2012), http://www.planalto.gov.br/ccivil_03/ _ato2011-2014/2012/lei/112715.htm

2. Reis, J., Oliveira Costa Neto, P.: Method for quality appraisal in supply networks. In: Emmanouilidis, C., Taisch, M., Kiritsis, D. (eds.) Advances in Production Management Systems. Competitive Manufacturing for Innovative Products and Services, IFIP Advances in Information and Communication Technology, vol. 398, 
pp. 519-526. Springer Berlin Heidelberg (Jan 2013), http://dx.doi.org/10.1007/ 978-3-642-40361-3_66

3. Brazilian Automotive Industry Association: Brazilian Automotive Industry Yearbook. Centro de Documentação da Indústria Automobilistica - CEDOC, São Paulo (2014), http://www .anfavea.com.br/anuario.html

4. DIEESE: A indústria automobilistica no Brasil: diagnóstico do setor e análise do novo regime automotivo (2012), http://www.smabc.org.br/Interag/temp_img/ $\% 7 B 57336$ FD0-AA1A-4ED1-92AA-DE866CE178DA\%7D_diagnostico\%20do\%20setor\% 20automotivo.uv.pdf

5. da Indústria de Componentes para Veículos Automotores Sindipeças, S.N.: Brazilian autoparts industry performance (2012), http://www.sindipecas.org.br/ arquivos/Desempenho_Autopecas_2012.pdf

6. Kutney, P.: Inovar-auto protege o lucro de montadoras ineficientes (2014), http: //www. automotivebusiness.com.br/artigo/827

7. Agência Brasileira de Desenvolvimento Industrial: Estudo prospectivo setorial automotivo (2009), http://www.abdi.com.br/Estudo/Automotivo.pdf

8. Rocha, A., Perrota, R., Vendrametto, R., Monteiro Junior, J.: Industrial warehouse under computerized customs control regime: some evidences from brazil. In: Managing Complexity: Challenges for Industrial and Operations Management. pp. 1-12. Abepro, Valladolid (2013)

9. Karasawa, T.: The strategy of japanese autoparts companies in Brazil (2013), http://www. automotiva-poliusp.org/wp-content/uploads/2013/ 03/Karasawa-vfinal.pdf

10. Ibusuki, U., Kobayashi, H., Jin, Y.: Asian automobile manufacturers strategies in Brazil: impact of the new automotive policy (INOVAR-AUTO). Paris (2013), http://gerpisa.org/en/node/2108

11. Brasil: Decreto 7.819/2012 (2012), http://www.planalto.gov.br/ccivil_03/ _ato2011-2014/2012/Decreto/D7819.htm

12. Kutney, P.: Toyota busca $65 \%$ de nacionalizao para motor brasileiro a ser feito em porto feliz (2014), http://www . automotivebusiness.com.br/noticia/19009

13. Riatto, G.: Com inovar-auto, cummins eleva nacionalizao (2014), http://www. automotivebusiness.com.br/noticia/19229

14. Kutney, P.: MCTI barra montadoras na lei do bem (2014), http://www. automotivebusiness.com.br/noticia/19326 